\title{
EFFICIENCY VERSUS COMPETITIVENESS IN ROMANIAN AGRICULTURE. CASE STUDY
}

Ion Raluca Andreea ${ }^{1}$, Dobre Iuliana ${ }^{2}$, Soproni Vasile Darie ${ }^{3}$

*Corresponding authorE-mail: raluca.ion@eam.ase.ro

\begin{abstract}
A R T I C LE IN F O
A B S T R A C T

Original Article

Received: 27 May 2019

Accepted: 27 June 2019

doi:10.5937/ekoPolj1903691R

UDC 33:631(498)

Keywords:

agricultural productivity, efficiency, farm competitiveness

Thepaperinvestigates the relationships between agricultural productivity, efficiency and farm's competitiveness, trying to find out to what extend the farm's activity is both efficient and competitive? The research starts from the assumption that a farm can be economically inefficient but competitive, and, reciprocally, an economically efficient farm is not necessarily competitive. A case study of a farm from North-West Romania has been considered. It was found that, although the overall activity of the farm is inefficient in some agricultural years, for certain crops, the farm is competitive in those regarding prices and yields. JEL: $Q 12$ The analysis goes deeper to compare crops between them and proposes solutions for increasing farm's efficiency by replacing inefficient crops to efficient ones, using the method of balance of gains and losses. The results of the research are useful in helping farmers making their decisions regarding the structure of production.
\end{abstract}

(C) 2019 EA. All rights reserved.

\section{Introduction}

Agricultural performance is at the center of many debates, policies and analysis concerning the farming sector. Global initiatives, such as the 2030 Agenda for Sustainable Development, placed agricultural productivity among other global issues. Growths in agricultural yields eases pressure on land use and raising the productivity of agricultural labor in developing countries, strengthens income and stimulates economic development (Fuglie, 2018). By reducing the quantities of inputs needed to produce food, higher agricultural productivity makes food cheaper and has a propagated e $\square$ ect on poverty reduction.

1 Ion Raluca Andreea, Associate Professor, Department of Agro-food and Environmental Economics, The Bucharest University of Economic Studies, 6, Piata Romana, sector 1, Bucharest, Romania, raluca.ion@eam.ase.ro, https://orcid.org/0000-0001-7182-5809

2 Dobre Iuliana, Associate Professor, Department of Agro-food and Environmental Economics, The Bucharest University of Economic Studies, 6, Piata Romana, sector 1, Bucharest, Romania, iulya_dobre@yahoo.com, https://orcid.org/0000-0002-8940-2289

3 Soproni Vasile Darie, Associate Professor, Department of Electrical Engineering, University of Oradea, 1-3, University Street, Oradea, Romania, vsoproni@uoradea.ro, https://orcid. org/0000-0002-0842-4524 
Predictions estimated that world population will rise, therefore it is expected that the global demand for food to increase, which will intensify the competition for scarce natural resources. Accordingly, the food production must increase. Since the land is limited, the agricultural output should grow intensively, by increasing productivity. Major increases in efficiency are needed to meet the land and water scarcity in agriculture (Hong et al. 2019), especially as the demand for these resources from nonagricultural sectors, such as biodiesel industry, is also rising (Dusmanescu et al., 2014).

In Romania, agriculture plays a significant role within the economy, considering the large agricultural area of 8,409,242 hectares under cultivation, representing 0.43 hectares per inhabitant, and the share of 4.8\% of agriculture in GDP, in 2018 (National Institute of Statistic, 2019). The main crops cultivated are cereals ( $65 \%$ of the agricultural area) and oil crops (19\% of the agricultural area). Among cereals, corn and wheat are the most cultivated. Corn holds $30 \%$ of total cultivated area and wheat holds $25 \%$. Among oil crops, sunflower holds $12 \%$ of total cultivated area, rape $5.4 \%$ and soybeans $1.5 \%$. The areas cultivated with oil crops have grown over the last years, as a result of increasing demand for biodiesel (Andrei et al., 2016).

Agriculture in Romania is characterized by numerous small family holdings and only several commercial farms. There are 3,342,185 agricultural exploitations in Romania, of which 351,894 hold under 1 hectare and 555,396 hold between 1 and 3 hectares. Only 12,310 farms exploit 100 hectares and over (National Institute of Statistic, 2019). Given that there are many types and forms of holdings, most of them family farms, the economic performance in agriculture is difficult to be assessed. When speaking about performance, productivity, efficiency and competitiveness, as its main components (Ion, 2005), are envisaged. The study of performance implies numerous economic and financial data on revenues and expenses registered in accountancy and many farms do not hold a system of bookkeeping. Small family farms hold empirical management, a minimum level of accounting, the quality of commodities largely varies (Soproni et al., 2008) or there are regional differences in labor expenditure and consumption (Voicu, Dobre, 2003). This is the reason why, when measuring performance, the commercial farms are investigated. In their cases, the characteristics of economic and financial activity and management are distinguished. It is well known that the type of management contributes to the economic performance of a farm, its effect being quantifiable at the propagated level. Certainly, in the case of commercial farms that have organized the accountancy according to the law in force, based on the existing information, the incomes, turnover, value added, gross and net profit can be assessed (Dobre et al., 2012).

This paper investigates the economic performance of a commercial farm in North-West Romania, in Satu-Mare County, the research objectives being to identify its determinants and components: productivity, efficiency and competitiveness. The question that this piece of research tries to answer is to what extend the farm's activity is both efficient and competitive? The hypothesis tested is based on previous research (Mechri et al., 2017), arguing that "a farm can be economically inefficient but competitive; reciprocally, 
an economically efficient farm is not necessarily competitive". The analysis goes deeper and compare crops between them and proposes solutions for increasing farm's efficiency by replacing one crop to another. In pursuing this, the method of optimizing the structure of production by replacing less efficient crops with more efficient ones is the method of balance of gains and losses (Voicu, Dobre, 2003). The final goal is to enhance performance by changing the structure of production, based on economic efficiency.

Since the bulk part of the scientific papers have studied competitiveness in an international approach, comparing national economies and products on world trade, this paper fill in the gap left in literature on agricultural performance at farm level, especially in Romania. This piece of research analysis the competitiveness from the farm's point of view, investigating its competitiveness at micro level. Moreover, the farm's activity is compared to the other farms that reported the economical results aggregated into average indicators at national level.

\section{Literature review}

Hundreds of studies have been published reporting definitions, analysis and measures of agricultural productivity, efficiency and competitiveness, as forms of performance.

Generally, the productivity is defined as a ratio of a volume measure of output to a volume measure of input use (OECD, 2001), regardless of the sector of activity. A special distinction that needs to be made is between agricultural productivity and efficiency. Generally, agricultural productivity is considered to depict the efficiency in its two forms - technical and economic efficiency (Grosskopf, 2002). The former measures how well the inputs are combined. When available inputs are used optimally, the production frontier is reached and a farm which reaches its production frontier means that is has also reached its maximum level of technical efficiency, according to Odhiambo (et al., 2004). The latter refers to marginal values and unit cost, thereby, a farm reaches economic efficiency when the marginal value of the inputs is equal to their respective unit costs, as explained by Kelly (et al., 1996).

Another distinction that needs to be made is between efficiency and competitiveness. While the first measures the economic performance of the farm, the second compares this performance to that of their competitors (Mechri et al., 2017). Moreover, competitiveness and productivity are closely linked, in the sense that higher productivity leads to a greater competitiveness of the farm because more output is produced of the same quantities of resources (Porter, 1990).

The notion of competitiveness has been approached from various perspectives that contribute to enrich the literature. Generally, competitiveness is defined as the ability of a production system to maintain or enhance its market position. Trail and Pitts (1998) argued that a competitive industry is one that possesses the sustained ability to profitably gain and maintain market share in domestic and/or foreign markets. Martin (et al., 1991) described the competitiveness drivers, among them productivity, 
technology, products, market structure, inputs, demand conditions, market relations. da Silva César (et al., 2019) also analyzed the competitiveness of soybeans and identified the drivers behind it.

Research on the measurement of agricultural productivity, efficiency and competitiveness is not new. It can be traced back to the classical theory of economic growth. Productivity measurement has its ground theory in the "theory of the firm" in which the inputs can be combined optimally to allocate scarce resources, allowing firms to maximize profits under a cost constraint or to minimize costs under an output constraint. A number of previous researchers have utilized empirical models and statistical methods to measure agricultural productivity. Defined as a ratio of output and input, when measuring productivity, the two determinants must be firstly assessed.

When measuring the output, either gross output or value added estimates can be used to calculate productivity (Mechri et al., 2017). In this piece of research, gross output is used, generally defined as the value of production. Usually, farms produce multiple products, therefore, a common unit for the output must be chosen, such as monetary value, calories and commodity-equivalent. In this paper, the monetary value has been used to express the output.

When measuring the input, three major categories are considered: land, labor and capital. It was found that the labor productivity gap between rich and poor countries is larger in the agricultural sector than in the rest of the economy (Restuccia et al., 2008). The same results have been found by Herrendorf and Schoellman (2015) who sustained that in poor countries, the labor productivity is considerably lower than in the rest of the economy. As regards land productivity, Fuglie (2018) argued that increased cropping intensity has compensated for declining growth in average yield per harvest to keep land productivity growth from falling.

Efficiency is measured from technical and economical points of view. Aignier (et al., 1977) and Meeusen and van den Broeck (1977) grounded the theory of technical efficiency and established the production frontier analysis to estimate its level. Economic efficiency is measured using monetary indicators. One of them is returns over cash costs calculated as the value of the outputs produced by the farm minus the value of the purchased inputs.

\section{Materials and methods}

For assessing the levels of productivity and efficiency, a case study of a farm from North-West Romania is considered. It exploits 460 hectares, cultivated with cereals, wheat and corn, and oil crops, sunflower, rape and soybeans.

Since land has a significant place in agriculture, as compared to other branches of economy, the land productivity is estimate using yield as main indicator. Land productivity measures the amount of output generated by a given amount of land. For example, a crop output per land area, commonly referred to as crop yield, is often cited 
as a land productivity measure. When expressed in monetary terms, land productivity is referred to as returns to land, according to Mechri (et al., 2017).

Table 1. The structure of production and land productivity

\begin{tabular}{|l|r|r|r|r|r|r|r|r|r|}
\hline \multirow{3}{*}{ Crop } & \multicolumn{4}{|c|}{ Area (hectares) } & \multicolumn{4}{c|}{ Area (\%) } & \multicolumn{3}{c|}{ Land productivity (kg/ha) } \\
\cline { 2 - 11 } & $2015 /$ & $2016 /$ & $2017 /$ & $2015 /$ & $2016 /$ & $2017 /$ & $2015 /$ & $2016 /$ & $2017 /$ \\
2016 & 2017 & 2018 & 2016 & 2017 & 2018 & 2016 & 2017 & 2018 \\
\hline Wheat & 195.21 & 160.97 & 159.58 & 43.9 & 35.0 & 35.1 & 5578 & 7053 & 4950 \\
\hline Corn & 120.36 & 149.59 & 150.1 & 27.1 & 32.5 & 33.0 & 7076 & 8684 & 8437 \\
\hline Rape & 49.25 & 42.59 & 49.74 & 11.1 & 9.3 & 10.9 & 3161 & 3656 & 4161 \\
\hline Soybeans & 31.83 & 34.08 & 35.57 & 7.2 & 7.4 & 7.8 & 3276 & 2791 & 3072 \\
\hline Sun flower & 48.19 & 72.41 & 60 & 10.8 & 15.8 & 13.2 & 3894 & 2151 & 3495 \\
\hline Total & 444.84 & 459.64 & 454.99 & 100 & 100 & 100 & & & \\
\hline
\end{tabular}

Source: farm's accountancy, authors' calculations

Figure 1. The structure of production, 2017/2018 (\%)

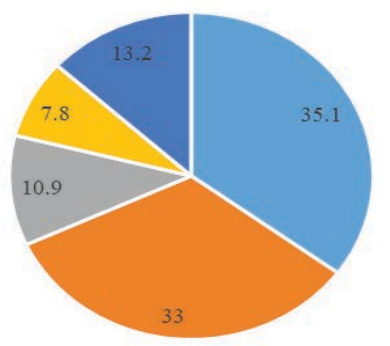

- Wheat $=$ Corn $=$ Rape $=$ Soybeans $=$ Sunflower

Source: farm's accountancy, authors' calculations

Figure 2. Crops' yields, 2015-2018 (kg/ha)

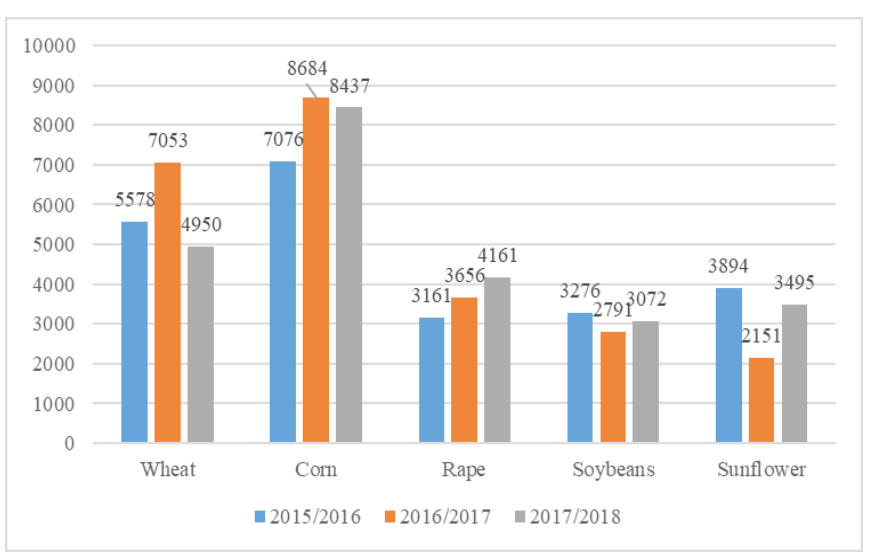

Source: farm's accountancy, authors' calculations 
The agricultural area of the farm under analysis is cultivated with wheat $(35 \%)$, corn $(33 \%)$, rape $(11 \%)$, soybeans $(7.8 \%)$ and sunflower $(13.2 \%)$, as seen in Table 1 and Figure 1. The land productivity is between 5 and 7 tons of wheat per hectare, 7-8.6 tons of maize per hectare, 3-4 tons of rape per hectare, 2.7-3.2 tons of soybeans per hectare and 2-3.8 tons of sunflower seeds per hectare (Table 1 and Figure 2). The yields vary depending on the amounts of inputs and the variability of weather.

Further, this subsection tries to ascertain to what extent efficiency, as form of productivity, and incomes are linked and how the nature of this relationship can vary depending on the type of crop (Table 2). It should be remembered that the level of production, income and expenses have multiple influences that come from factors that change annually what is done at the farm level. In this context, the factor analysis starts from average production, sales prices and production costs. With regard to the production, sales price, production costs and the result of the financial year, different values are recorded, which corresponds to the conditions in which the market acts. Natural elements and the relevance of the management decisions are added.

Total wheat production has varied and the sales price has risen. Prices tend to rise from USD 0.12 to USD 0.15 , but their influence in revenue is not significant, because they are negatively increasing. The volume of expenses, expressed in absolute terms, is considerable in the period 2016-2017, but with a downward trend, in the context of large fluctuations in the market.

As regards maize, the maximum total production is 1299,08 tons in $2016 / 2017$, with an equal selling price between 2016-2018 and a low production value in 2015 compared to the 2016-2018. Spending on hectares has fallen in 2016/2017, and then it raised in $2017 / 2018$.

Regarding the rapeseed, the sales price has risen (from USD 0.33 to USD 0.35), which paves the stability of this crop on the market. The cost and production value in the period under review are steadily rising, signalizing the economic importance of this culture. Its role within the economy is widely than agriculture, going behind other industries, such as biodiesel (Turek-Rahoveanu et al., 2018).

With regard to soybean culture, production is oscillating as the shoulder of natural factors. Demand for processed products has aroused the need for soybean cultivation. The value of production, calculated between 2015 and 2018, has a parabolic shape with low slopes, from USD 767.3, in 2015/2016, to USD 934.7 in 2016/2017 and USD 863.5 in $2017 / 2018$.

Sunflower, considered a rapacious crop because it consumes the nutrients from soil, has a growing production. The sale price dropped between 2015 and 2018, from USD 0.31 to USD 0.27 , which is insignificantly economic, because it still returns positive results. 
Table 2. Production values, expenses and results, by crop, 2015-2018

\begin{tabular}{|c|c|c|c|c|}
\hline Crop & Item & $2015 / 2016$ & $2016 / 2017$ & $2017 / 2018$ \\
\hline \multirow[t]{5}{*}{ Wheat } & Production $(\mathrm{kg})$ & 1088930 & 1135440 & 790000 \\
\hline & Price (USD/kg) & 0.12 & 0.14 & 0.15 \\
\hline & Production value (USD/ha) & 653.2 & 991.2 & 718.8 \\
\hline & Expenses (USD/ha) & 701.4 & 1073.6 & 902.1 \\
\hline & Results (USD/ha) & -48.2 & -82.4 & -183.3 \\
\hline \multirow[t]{5}{*}{ Corn } & Production $(\mathrm{kg})$ & 851684 & 1299080 & 1266400 \\
\hline & Price (USD/kg) & 0.09 & 0.12 & 0.12 \\
\hline & Production value (USD/ha) & 662.9 & 1016.9 & 987.9 \\
\hline & Expenses (USD/ha) & 849.3 & 823.2 & 977.7 \\
\hline & Results (USD/ha) & -186.4 & 193.7 & 10.3 \\
\hline \multirow[t]{5}{*}{ Rape } & Production $(\mathrm{kg})$ & 155700 & 155747 & 206970 \\
\hline & Price (USD/kg) & 0.33 & 0.33 & 0.35 \\
\hline & Production value (USD/ha) & 1036.5 & 1199.0 & 1461.7 \\
\hline & Expenses (USD/ha) & 704.8 & 773.2 & 1117.2 \\
\hline & Results (USD/ha) & 331.7 & 425.8 & 344.5 \\
\hline \multirow[t]{5}{*}{ Soybeans } & Production $(\mathrm{kg})$ & 104285 & 95120 & 109297 \\
\hline & Price (USD/kg) & 0.23 & 0.33 & 0.28 \\
\hline & Production value (USD/ha) & 767.3 & 934.7 & 863.5 \\
\hline & Expenses (USD/ha) & 755.5 & 999.9 & 978.3 \\
\hline & Results (USD/ha) & 11.8 & -65.2 & -114.8 \\
\hline \multirow[t]{5}{*}{ Sunflower } & Production $(\mathrm{kg})$ & 187656 & 201363 & 209670 \\
\hline & Price (USD/kg) & 0.31 & 0.29 & 0.27 \\
\hline & Production value (USD/ha) & 1203.8 & 814.1 & 949.3 \\
\hline & Expenses (USD/ha) & 899.0 & 770.3 & 872.9 \\
\hline & Results (USD/ha) & 304.8 & 43.8 & 76.4 \\
\hline
\end{tabular}

Source: farm's accountancy, authors' calculations

Figure 3. Production values, expenses and results, all crops, 2015-2018 (USD)

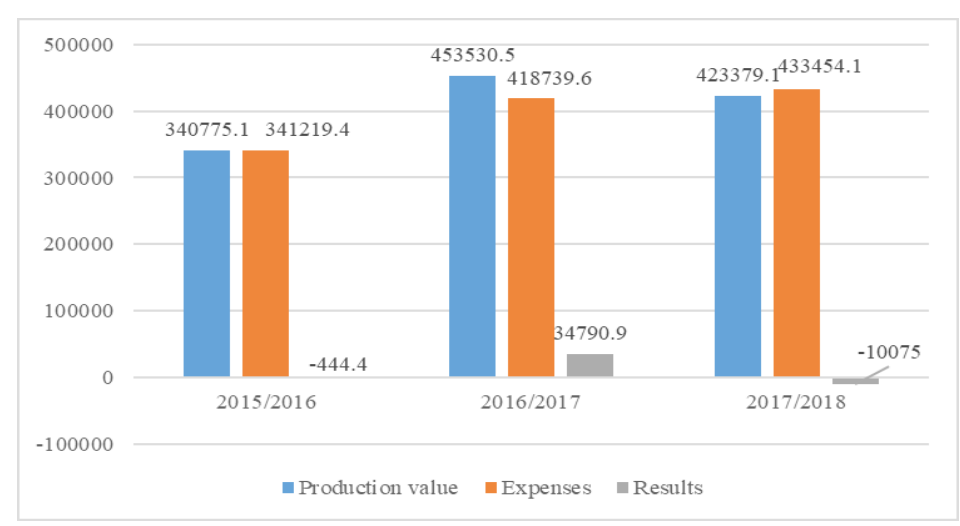

Source: farm's accountancy, authors' calculations 
The overall agricultural activity of the farm is efficient in the agricultural year 2016/2017, when the difference between production values and expenses is positive, equal to USD 34,790.9. The crops' cultivation activity is inefficient in the years 2015/2016 and 2017/2018, when the returns are negative, USD -444.4, USD -10,075, respectively (Figure 3).

When measuring the level of efficiency, the output taken into account is turnover and profit, and the input is total expenditure (Figure 4).

Figure 4. Turnover, income, expenses and results, overall activity, 2015-2018 (USD)

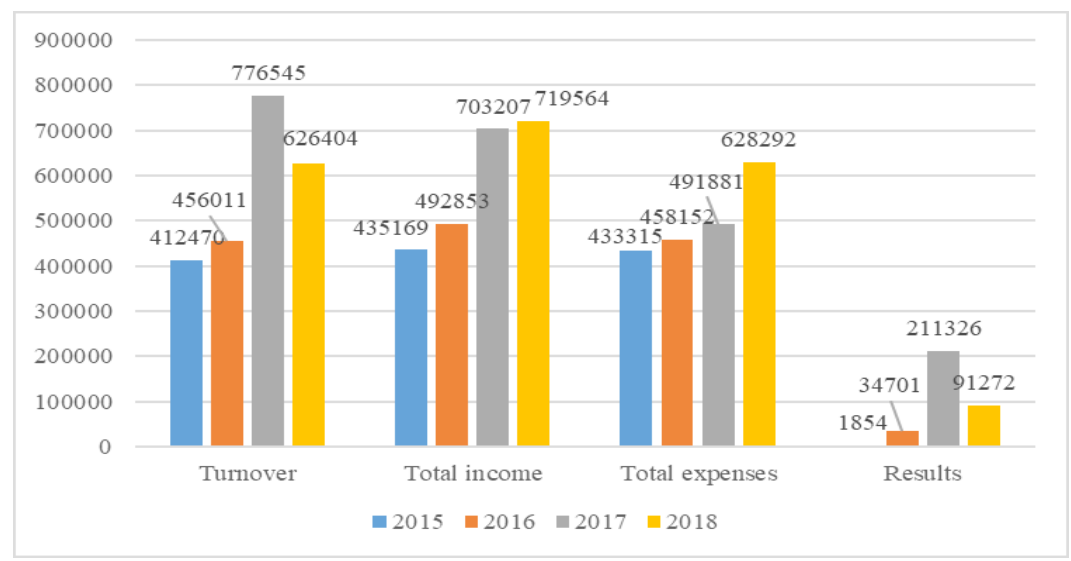

Source: farm's accountancy, authors' calculations

Turnover has the maximum value in 2017, as a result of increased production. Total revenue has increased over the period under analysis. As far as expenses are concerned, they have increased from USD 433,315 in 2015, to USD 628,292 in 2018. The results are positive, reaching a peak of USD 211,326, in 2017. The rate of return has changed in the sense of growth, its values, calculated as ratio between gross profit and total expenditure, are $0.43 \%$, in 2015 , and $42.96 \%$, in 2017 . Variations in this period relate to the weather variability and market conditions. The profit margin is reduced in 2015 $(0.45 \%)$ and it has risen to $27.21 \%$ in 2017.

The overall activity of the farm is efficient for the whole period 2015-2018, although the efficiency of the agricultural activity, solely, is not efficient every year. One reason could be that, besides the activity of cereals and oil crops cultivation, the farm earns income from the provision of agricultural services and rental of machinery and equipment.

\section{Efficiency and productivity versus competitiveness}

In this section, the farm's activity is analyzed from the competitiveness point of view, relatively to the results of other businesses within the agricultural sector, at national and local level (Satu Mare county, in North-West Romania). Its efficiency and productivity is compared with farm's competitors. 
Trail and Pitts (1998) consider that there are three approaches when measuring competitiveness. The first one is from the point of view of performance, which looks how well an economic entity has done relative to its competitors. Typical measures are profitability, growth, market share etc. The second one measures the competitive potential, looking at the availability or quantity of inputs, which may produce superior performance such as access to superior technology or cheaper raw materials, leading to lower costs and higher productivity. The third one measures the competitive process, trying to find solutions to convert the competitive potential into competitive performance.

The farm activates in the sector of cereals, oil crops and pulses. The data issued by the Ministry of Public Finance of Romania (2019) show that, at national level, this sector comprises 8,609 economic agents $(0.44 \%$ of all Romanian agents), 44,445 employees ( $1.11 \%$ of all Romanian employees). The turnover was billion USD 4.5 (1.42\% of its national level) and the profit was million USD 680, in 2017. At local level, it comprises 202 economic agents, 964 employees. The turnover was million USD 132 and the profit million USD 13.6, in 2017 (Table 3).

The farm registered a turnover of USD 776,545 in 2017. The profit margin registered $27 \%$, above its average level of $10.3 \%$ within sector at local level and $15 \%$ at national level. The labor productivity is USD 97,068.1 per employee, lower than its national level of USD 101,248.7 per employee and its local level of USD 136,929.5 per employee.

Table 3. Turnover, profit, profit margin, number of employees and labor productivity at national, local and farm level

\begin{tabular}{|l|r|r|r|l|l|}
\hline Item & Turnover (USD) & Profit (USD) & $\begin{array}{l}\text { Profit margin } \\
(\%)\end{array}$ & $\begin{array}{l}\text { No. of } \\
\text { employees }\end{array}$ & $\begin{array}{l}\text { Labor productivity } \\
\text { (USD/ employee) }\end{array}$ \\
\hline National level & $4,500,000,000$ & $680,000,000$ & 15.11 & 44,445 & $101,248.7$ \\
\hline Local level & $132,000,000$ & $13,000,000$ & 9.85 & 964 & $136,929.5$ \\
\hline Farm & 776545 & 211,326 & 27.21 & 8 & $97,068.1$ \\
\hline
\end{tabular}

Source: authors' calculation based on data from Ministry of Public Finance of Romania and farm accountancy

Labor productivity is often linked to land and capital. It was noticed that labor productivity in agriculture has increased in the last years because of the growth in crop yields globally (Kelly et al., 1996). This increase is the result of changes in agricultural technologies, such as increased mechanization that requires less labor, using improved quality seeds, which return higher yields, using larger amounts of chemical fertilizers and pesticides. Since these changes occurred mostly in developed countries, the gaps in agricultural productivity across countries and regions can be partially explained by the wider use of machineries, pesticides, chemical fertilizers and improved quality seeds in developed countries, in comparison to developing countries. This is the case of the farm under analysis, which uses lower amounts of chemical fertilizers, pesticides and machineries, as compared to the sector at local and national level. 
Land productivity, expressed by the indicator crop yields, is presented in Figure 5, at farm, local and national levels. The level of yield obtained within the farm for wheat, maize, rapeseeds and soybeans are higher than their levels obtained, on average, at national and local level, meaning that the farm has higher land productivity for these crops compared to its competitors. Sunflower seeds registered a yield below its levels registered, on average, by national and local competitors, signalizing that the land productivity for sunflower seeds is lower than its competitors.

Figure 5. Land productivity, $2017(\mathrm{~kg} / \mathrm{ha})$

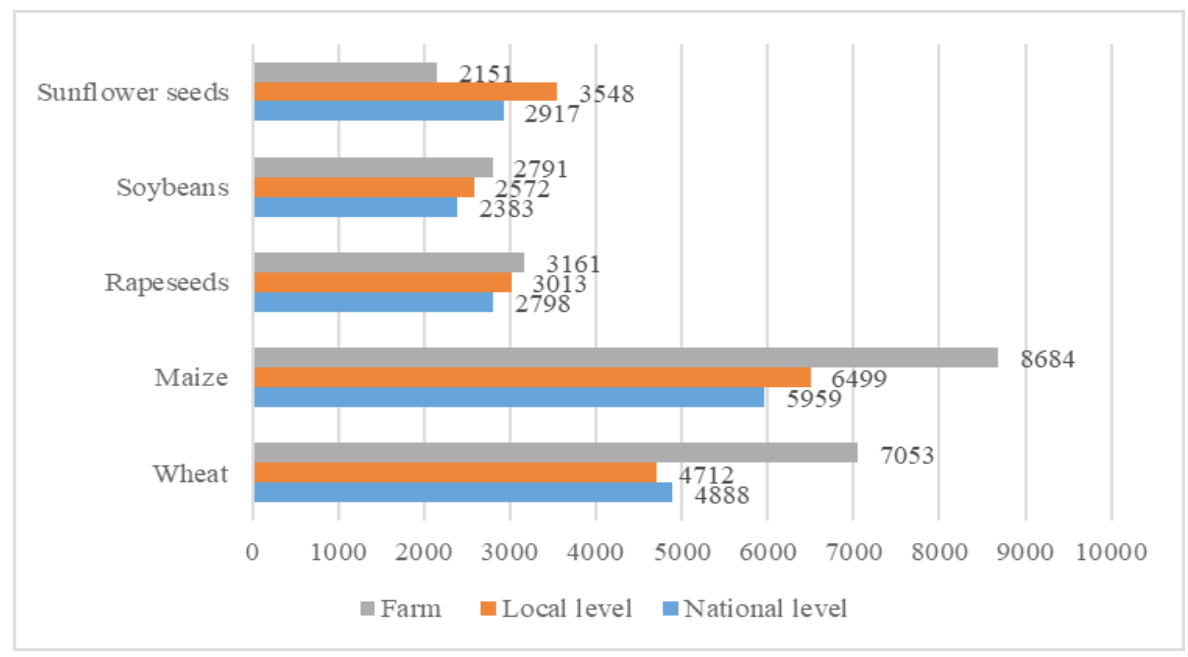

Source: farm's accountancy, National Institute of Statistic of Romania

Figure 6. Prices of wheat, maize, rapeseeds, soybeans and sunflower seeds (USD/kg)

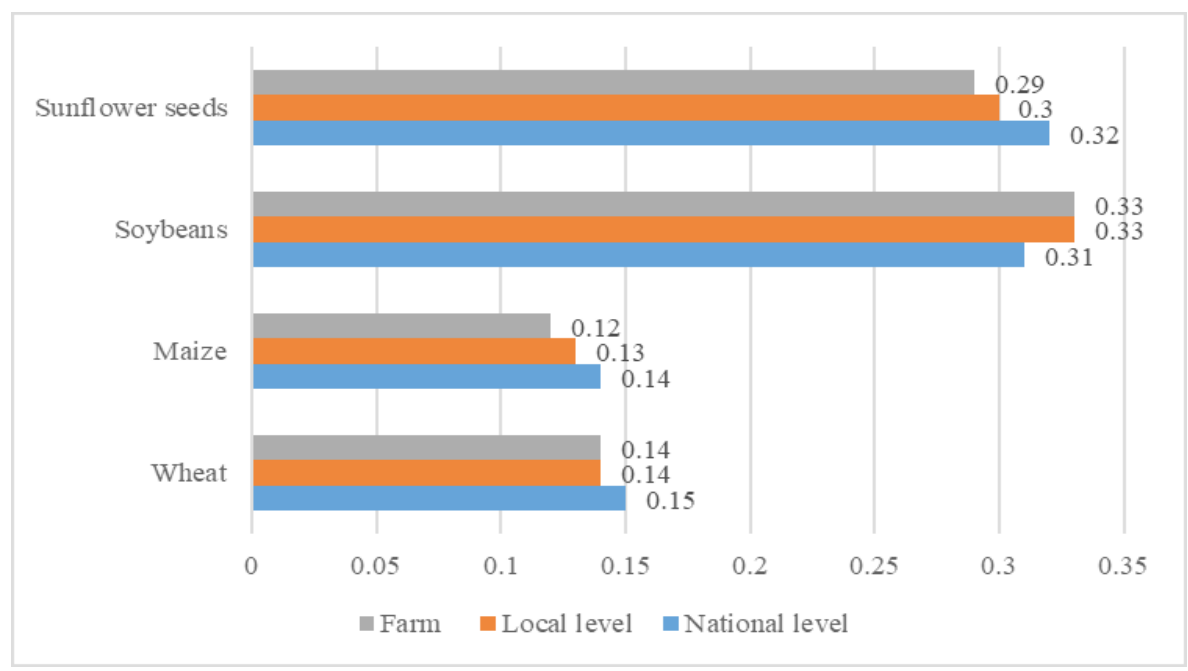

Source: farm's accountancy, National Institute of Statistic of Romania 
The enterprise's competitiveness can be measured considering its costs, prices, the quality of products and services (Zahiu, Nastase, 2002). When comparing the prices of products sold by the farm to their average levels at national and local points (Figure $6)$, they are lower or equal to national and local prices for all products: wheat, maize, soybeans and sunflower seeds, except soybeans price which is higher than its national level. We may argue that the farm is competitive, from the price point of view, because its products' prices are lower than the average prices of its competitors.

\section{Enhancing efficiency}

In order to increase the efficiency of the farm's activity, it is essential to predict what happens with crops during a statistical year, starting from variations in yields per hectare, product sales prices and production costs. The indicators considered within the analysis are viewed starting from the economic situation in the previous period and from the market conjuncture. The balance takes into account the gains and losses from crops that are replaced and for crops that are introduced into the structure of production. Prices' changes as a result of the supply-demand ratio and the influence of natural conditions on yield lead to a certain degree of risk in their estimation. Different levels of yields for the crop that is introduced into the structure and a change in the sales price of the product obtained from the replaced crop are possible. As a result, the level of the revenue from crop replacement may be higher or lower.

Following, scenarios are used to identify, according to the mentioned indicators, the crops that provide, by price and demand, values for increasing the level of agricultural activity's efficiency. Considering the losses registered in the year 2016/2017, two crops that are inefficient, wheat and soybeans, are considered to be replaced, and three crops, corn, rapeseed and sunflower, which are efficient, will be introduced into the structure of production.

Based on the calculations presented in Table 4, regarding revenues and expenses for each crop, expressed in USD per hectare, the highest efficiency is obtained when wheat is replaced by rape, because the difference between gains and losses is USD 508.2 per hectare, compared to scenarios where wheat is replaced by corn, when the difference is USD 276.1 per hectare and in which wheat is replaced by sunflower, in which case the difference is USD 126.2 per hectare.

In what concerns soybean culture, the balance shows that the highest efficiency is obtained when it is replaced by rape, in which case the difference between gains and losses is USD 491 per hectare, compared to scenarios where soy is replaced by corn, when the difference is USD 258.9 per hectare, and when soy is replaced by sunflower, when the difference is USD 109 per hectare.

Therefore, the efficiency of the farm's activity increases as a result of the replacement of part of the areas cultivated with less efficient crops, wheat and soybean, with efficient ones, such as rape, whose efficiency is rising as a results of a high level of price, due to demand from other industries, such as biodiesel. 
Table 4. Gains and losses balance when wheat and soybeans are replaced by corn, rape and sunflower (USD/ha)

\begin{tabular}{|c|c|c|c|}
\hline Crop replaced & Gains & Losses & Crop introduced \\
\hline \multirow[t]{3}{*}{ wheat } & 1073.6 & 991.2 & corn \\
\hline & 1016.9 & 823.2 & \\
\hline & 2090.4 & 1814.4 & \\
\hline gains-losses & & 276.1 & \\
\hline \multirow[t]{3}{*}{ wheat } & 1073.6 & 991.2 & rape \\
\hline & 1199.0 & 773.2 & \\
\hline & 2272.5 & 1764.4 & \\
\hline gains-losses & & 508.2 & \\
\hline \multirow[t]{3}{*}{ wheat } & 1073.6 & 991.2 & sunflower \\
\hline & 814.1 & 770.3 & \\
\hline & 1887.6 & 1761.5 & \\
\hline gains-losses & & 126.2 & \\
\hline \multirow[t]{3}{*}{ soybeans } & 999.9 & 934.7 & corn \\
\hline & 1016.9 & 823.2 & \\
\hline & 2016.8 & 1757.9 & \\
\hline gains-losses & & 258.9 & \\
\hline \multirow[t]{3}{*}{ soybeans } & 999.9 & 934.7 & rape \\
\hline & 1199.0 & 773.2 & \\
\hline & 2198.9 & 1707.9 & \\
\hline gains-losses & & 491.0 & \\
\hline \multirow[t]{3}{*}{ soybeans } & 999.9 & 934.7 & sunflower \\
\hline & 814.1 & 770.3 & \\
\hline & 1814.0 & 1705.0 & \\
\hline gains-losses & & 109.0 & \\
\hline
\end{tabular}

Source: authors' calculations based on farms' accountancy

\section{Conclusions}

This study has examined the relationship between productivity, efficiency and farm's competitiveness. The results show that the relationships between these are not always positive, which validates the hypothesis established ahead that a farm can be economically inefficient but competitive; reciprocally, an economically efficient farm is not necessarily competitive.

It was found that, although the overall activity of the farm is inefficient in some agricultural years, the farm is competitive compared to its competitors, in those regarding prices and yields. The crops' cultivation activities were inefficient in the years 2015/2016 and 2017/2018, when the returns are negative. Among crops, wheat, corn, in 2015/2016, soybeans, in 2016/2017 and 2017/2018, cultivations were inefficient. Meanwhile, the farm is competitive, from the price point of view, because its products' 
prices are lower than the average prices of its competitors. The farm is also competitive from the point of view of land productivity. The levels of yields obtained within the farm for wheat, maize, rapeseeds and soybeans are higher than their levels at national and local level. All these confirm the hypothesis that a farm can be economically inefficient but competitive.

Moreover, it was found that sunflower seeds registered a yield below its levels registered, on average, by national and local competitors, signalizing that the land productivity for sunflower seeds is lower. However, sunflower is one of the most efficient crop within the structure of production, what strengthens the hypothesis that an economically efficient crop is not necessarily competitive.

The relevance of the research lies in its capacity to make a clear understanding of the concepts of performance, productivity, efficiency, and competitiveness, their measurement and significance. It also highlights the special attention that should be paid to agriculture when measuring its performance, considering its features referring to unpaid labor supplied by the family members, the lack of accountancy, land as a key capital input, the significant volume of inputs that can originate from the farm itself and the outputs that are often consumed on the farm. All these make the agricultural input and output and, consequently, the productivity and efficiency, difficult to be assessed.

\section{Acknowledgements}

This work was supported by a grant of the Ministry of Research and Innovation, CNCS - UEFISCDI, project number PN-III-P4-ID-PCCF-2016-0166, within the PNCDI III project "ReGrowEU - Advancing ground-breaking research in regional growth and development theories, through a resilience approach: towards a convergent, balanced and sustainable European Union".

The authors wish to thank Vasile Soproni, manager of the farm Terra Sanislau, Satu Mare, Romania, for providing technical assistance in collecting the economic and field data.

\section{Conflict of interests}

The authors declare no conflict of interest.

\section{References}

1. Aignier, D., Lovell, K., C.A., \& Schmidt, P. (1977). Formulation and Estimation of Stochastic Frontier Production Function Models. Journal of Econometrics, 6(1), 21-37.

2. Andrei, J.,V., Ion, R.A., Popescu, G., Nica, E., \& Zaharia, M. (2016). Implications of agricultural bioenergy crop production and prices in changing the land use paradigm - The case of Romania. Land Use Policy, 50, 399-407.

3. Ball, V. E., \& Norton, G.W. (Eds.). (2002). Agricultural Productivity: Measurement and Sources of Growth. Springer, Berlin. 
4. Dobre, I., Voicu, R., \& Stefan, M. (2012). Gross margin - instrument to choice of activities from semi-subsistence agricultural exploitations. Quality-Access to success. Supplement, 141-145.

5. Dusmanescu, D., Andrei, J., \& Subic, J. (2014). Scenario for Implementation of Renewable Energy Sources in Romania. Procedia Economics and Finance, 8, 300-305.

6. Fuglie, K. (2018). Is agricultural productivity slowing? Global Food Security 17, 73-83.

7. Grosskopf, S. (2002). Some Remarks on Productivity and its Decomposition. Journal of Productivity Analysis, 20(3), 459-474.

8. Herrendorf, B., \& Schoellman, T. (2015). Why is measured productivity so low in agriculture? Review of Economic Dynamics 18(4), 1003-1022.

9. Hong, Y., Heerink, N., Zhao, M., \& van der Werf, W. (2019). Intercropping contributes to a higher technical efficiency in smallholder farming: Evidence from a case study in Gaotai County, China. Agricultural Systems, 173, 317-324.

10. Ion, R.A. (2005). Economic performance of the Romanian agro-food system. CERES, Bucharest. [in Romanian: Performanța economică a sistemului agroalimentar românesc].

11. Kelly, V.A., Hopkins, J., Reardon, T., \& Crawford, E.W. (1996). Improving the measurement and analysis of African agricultural productivity promoting complementarities between micro and macro data, Technical Paper No. 27, Office of Sustainable Development. Bureau for Africa. USAID publication, Washington, D.C.

12. Martin, L., Westgren, R., \& van Duren, E. (1991). Agribusiness Competitiveness across National Boundaries, American Journal of Agricultural Economics, 73(5), 1456-1464.

13. Mechri,A., Lys, P., \& Cachia, F. (2017). Productivity and Efficiency Measurement in Agriculture: Literature Review and Gaps Analysis. Technical Report Series GO-19-2017. FAO, Rome.

14. Meeusen, W., \& van den Broeck, J. (1977). Efficiency Estimation from CobbDouglas Production Functions with Composed Error. International Economic Review, 18(2), 435-444.

15. Ministry of Public Finance of Romania. (2019). Database.

16. National Institute of Statistic of Romania. (2019). Database.

17. Odhiambo, W., Nyangito N.O. \& Nzuma, J. (2004). Sources and determinants of agricultural growth and productivity in Kenya, KIPPRA Discussion Paper No. 34, Kenya Institute for Public Policy Research and Analysis, Nairobi.

18. OECD. (2001). Measuring Productivity - OECD Manual: Measurement of Aggregate and Industry-level Productivity Growth. OECD, Paris.

19. Porter, M. (1990). The Competitive Advantage of the Nations. Harvard Business Review, March-April, 71-91.

20. Restuccia, D., Tao Yang, D., \& Zhu, X. (2008). Agriculture and aggregate productivity: A quantitative cross-country analysis. Journal of Monetary Economics, 55(2), 234-250. 
21. da Silva César, A., Conejero, M.A., Barros Ribeiro, E.C., \& Batalha, M.O. (2019). Competitiveness analysis of "social soybeans" in biodiesel production in Brazil. Renewable Energy, 133, 1147-1157.

22. Soproni, V.D., Hathazi, F.I., Molnar, C.O., Arion, M.N., \& Pantea, M.D. (2008). The measurement of dielectric properties related to agricultural products. Annals of the Oradea University. Fascicle of Management and Technological Engineering, Volume VII (XVII), 579-586.

23. Trail, B., \& Pitts, E. (1998). Competitiveness of the Food Industry. Thomson Science, London.

24. Turek Rahoveanu, A., Turek Rahoveanu, M.M., \& Ion, R.A. (2018). Energy crops, the edible oil processing industry and land use paradigms in Romania-An economic analysis. Land Use Policy, 17, 261-270.

25. Voicu, R., \& Dobre, I. (2003). Organization and Development Strategy of Agricultural Units. Publishing House ASE, Bucharest. [in Romanian: Organizarea si strategia dezvoltarii unitatilor agricole].

26. Zahiu, L., \& Nastase, M. (2002). The Economy of Enterprise. ASE, Bucharest. [in Romanian: Economia întreprinderii] 